\title{
Molecular Identification of Trichogramma Species Present in Alhassa Oasis
}

\author{
M.J. Hajjar*, K.A. Alhudaib, M. Almasoud, M.I. Al-Maghaslah and S.M. El-Ganainy \\ College of Agricultural and Food Sciences, King Faisal University, Saudi Arabia \\ *Corresponding author
}

\section{Ke ywords}

Trichogramma, ITS2, Sequence, Spacer region of rDNA, PCR

Article Info

Accepted:

17 November 2018

Available Online:

10 December 2018
A molecular key based on the sequence of the internal transcribed spacer (ITS) of the ribosomal cistron was used for the identification of common Trichogramma (Hymenoptera: Trichogramma tidae) species found in agricultural field of Alhassa oasis in Saudi Arabia. The aligned sequences were checked using BLAST program at GenBank. The sequences of the three ITS region were the same and shared identities ranged from 98.3 to 99.4\% against all Trichogramma cacoeciae sequences at the GenBank. To our knowledge, it is the first report of distinguished Trichogramma cacoeciae in Alhassa, Oasis Saudi Arabia.

\section{Introduction}

Local species of Trichogramma are adapted to the climate and hosts. Therefore, they are generally preferred for inundated releases than exotic species, for the control of Lepidopteran species in Alhassa fields. The success of the Trichogramma species in biological control depends on their identification in the field, collection, maintenance and behavior in the laboratory, and selection of adequate species or strains (Özder and Kara, 2010). Biological control programs means; introduction of natural enemies predator or parasite to control certain types of pests into the field. Such programs impose high requirements on selectivity of chemical control agents and also know the side effect of chemicals on the natural enemies.Biological control programs means; introduction of natural enemies predator or parasite to control certain types of pests into the field. Many lepidopteran insects like Ephestia calidella, their development and lesion are limited to plants by using biological control agents such as Trichogramma parasites on invasive pest eggs. Parasitoid Trichogramma was used successfully in economic biological pest control programs and was considered an important natural safe way to control pests. However, Trichogramma spp. are now produces the by Government and private sectors by mass rearing, and used more 
than any other natural enemy in the biological control programs (Harris, 1973 and Stimer, and house 1990). The eggs parasitoid of Trichogramma species (Hymenoptera: Trichogrammatidae) are the major and influential factors in natural and agricultural ecosystem. It is effective in controlling and reducing the density of lepidopteran insects on many plant hostess, (Godfray, 1994) therefore Trichogramma have been used extensively worldwide as a biological control agent for Lepidopteran insects and reduce their lesions on plants, (Beserra and Parra, 2004). The integrated outcomes and success in the process of integrated pest management (IPM) are associated with timing and selection of insecticide used, in addition to the prevailing weather conditions at the time (Thomson et al., 2000; Jiu-Sheng, 2010). Trichogramma species are difficult to identify because they are both very small and have few distinguishing morphological characteristics. The genus Trichogramma was established in 1833 with Trichogramma evanescens Westwood. The family Trichogrammatidae contains 80 genera and approximately 620 species (Pinto and Stouthamer, 1994). However, the ambiguity of Trichogramma identification was illuminated by several morphological characteristics, such as phragma, which the differences are constant. In addition, the wing, pigmentation and antennal trichiation are unstable and may be influenced either by temperature or by the hosts on which wasps are reared (Nagarkatti \& Nagaraja, 1977; Landry et al., 1993).

The most important step for the successful introduction of Trichogramma spp. in biological control programs is to identify the most effective species that attack a target pest. Since correct identification of these minute wasps is essential. The tools of genetic means have become the routine and reliable identification of Trichogramma species. Recent studies have focused on the use of the
DNA sequence of internal transcribed spacer (ITS2) regions of nuclear rRNA for species identification, (Ercan et al 2011; Kumar et al., 2016). However the species of Trichogramma were identified genetically in most part of the world as were described in the recent publications, where in China they characterized of differences between two Trichogramma wasps by molecular markers (Chang et al., 2001), in Mediterranean region, Sumer et al., (2009) set a molecular key to the common species of Trichogramma of the region. Moreover in Brazil, Santos, et al. (2015) used molecular identification of Trichogramma species from regions, and in Pakistan, Nasir et al., (2013), used ITS-2 region of rDNA, for molecular identification of Trichogrammas species. The present study used PCR amplification of ITS2 region from genomic DNA to identify the species of Trichogramma wasps which are present in Alhassa agricultural fields.

\section{Materials and Methods}

\section{Trichogramma cultures}

The parasitoid Trichogramma spp. were collected from eggs of Lepidoptera insects had laid on leaves of plants cultivated in Alhassa fields, that were during the local growing season of vegetables from September to May 2015. The collected leaves with eggs were brought to the entomological laboratory equipped with controlled insect growth chamber for mass rearing of parasitoid, in department of sustainable palm pest's control, at excellence research center for palms and dates, King Faisal University. The emerged parasitoids were introduced to eggs of date's moth E. cautella irradiated with UV and scattered on pieces of cardboard stickers. In addition cardboard $(3 \times 4 \mathrm{~cm})$ with scattered eggs of date's moth, were distributed in the fields cultivated with tomatoes and alfalfa, Cucurbits. The cardboard were inspected 
periodically and if the eggs on the cardboard stickers showed a symptoms of intruding, they were transferred to laboratory and each sticker was kept into tubed vials $(5 \mathrm{~cm}$ diameter and 8 $\mathrm{cm}$ high) with strips of filter paper, into controlled insect growth chamber at $25 \pm 2{ }^{\circ} \mathrm{C}$, $75 \pm 20 \% \mathrm{RH}$, and a daylight of 16:8 (L:D) till the parasites that parasitized the eggs were emerged. However, the parasitized eggs of $E$. cautella were collected separately from three field of tomato, alfalfa, and cucurbit plants and were separately incubated till the adults stage of parasitoid Trichgramma spp merged. The emerged adults were collected into small vials using an aspirator, and were reared in UV irradiated eggs of date's moth $E$. cautella pasted on strips of cardboards to obtain the F2 of Trichgramma spp. The adults of F2 generation were collected after mating and laying eggs in E. cautella. and kept in $96 \%$ ethanol maintained as a sample for molecular identification, labeled with all required data include (site location, cultivated plants, the host insect, date of collection and the name of the person who collected)

\section{Extraction of the total DNA from Trichogramma samples}

The three labeled samples of Trichgramma spp. originated from the three separated fields were extracted in the molecular laboratory, at pest and plant diseases unit (PPDU), King Faisal University (KFU). Each killed wasp was grounded with pestle and liquid nitrogen then the ground sample was suspended in 580 $\mu \mathrm{L}$ of SDS extraction buffer solution $(200 \mathrm{mM}$ Tris- $\mathrm{HCl} \mathrm{pH} 8,25 \mathrm{mM}$ EDTA $\mathrm{pH} 8.0,0.5 \%$ SDS, and $250 \mathrm{mMNaCl}$ ) and $8 \mu \mathrm{L}$ of RNase A solution $(100 \mathrm{mg} / \mathrm{mL})$ was added. The ground samples were vortexed for 10 seconds for proper mixing and incubated at $37^{\circ} \mathrm{C}$ for 1 hour in water bath. Ten $\mu \mathrm{L}$ of Proteinase $\mathrm{K}$ solution $(20 \mathrm{mg} / \mathrm{mL}$ ) was added and mixed gently then incubated at $50{ }^{\circ} \mathrm{C}$ overnight. Equal volume of PCI $(25: 24: 1)$ was added.
The tubes were vortexed for $15 \mathrm{sec}$ and centrifuged for 10 minutes at $10000 \mathrm{rpm}$. The supernatant was transferred into new $1.5 \mathrm{~mL}$ Eppendorf tube then $1 / 10$ volume of $3 \mathrm{M} \mathrm{Na}$ acetate $(\mathrm{pH} 5.2)$ with 2 to 2.5 volume of chilled absolute ethanol was added and mixed by inverting the tube and Centrifuged at $10,000 \mathrm{rpm}$ for $15 \mathrm{~min}$ at $4^{\circ} \mathrm{C}$. The supernatant fluid was removed and the pellet was washed with $800 \mu \mathrm{L}$ of $70 \%$ ethanol and centrifuged for 3 minutes at $10000 \mathrm{rpm}$. The supernatant was discarded completely without disturbing the DNA pellet and the pellet was dried at room temperature. The DNA was resuspended in $100 \mu \mathrm{L}$ TE buffer. Finally the DNA samples were stored at $-20^{\circ} \mathrm{C}$.

\section{PCR amplification of ITS2 region from the DNA of wasps}

Forward primer,ITS2F 5'- TGTGAACT GCAGGACACATG -3' and Reverse primer, ITS2R 5'- GTCTTGCCTGCTCTGAG -3' (Stouthamer et al., 1999) were used to amplify the corresponding genomic fragments of the wasp according to Stouthamer et al., (1999).

PCR was done in a $25-\mu 1$ reaction containing 1 $\mu 1$ of the DNA extract (40 ng of total DNA), 2 $\mathrm{mM} \mathrm{MgCl} 2,2.5$ of $10 x$ PCR buffer, $1.5 \mu \mathrm{L}$ of $10 \mu \mathrm{M}$ of each primer, $2.5 \mu \mathrm{l}$ of $10 \mathrm{mM}$ dNTPs, $0.3 \mu \mathrm{l}$ of $5 \mathrm{U}$ Taq DNA Polymerase and the reaction was completed to $25 \mu \mathrm{l}$ with Nuclease-free water. PCR was conducted in the ESCO Swift Maxi Thermal Cycler with primary denaturation at $94^{\circ} \mathrm{C}$ for $2 \mathrm{~min}$, then by 30 cycles of $94^{\circ} \mathrm{C}$ for $30 \mathrm{Sec}, 58^{\circ} \mathrm{C}$ for 30 $\mathrm{Sec}$, and $72^{\circ} \mathrm{C}$ for $30 \mathrm{Sec}$, and the final cycle was polymerization performed at $72^{\circ} \mathrm{C}$ for 2 $\min$.

The obtained PCR products were loaded on $1.5 \%$ agarose gel, $100 \mathrm{~b}$ pladders was used as a reference for sizing of amplified PCR fragments. Five Easy Stain II $\mu 1$ was added to $100 \mathrm{ml}$ agarose solution and DNA fragments 
were visualized by UV illumination using Gel Documentation System. The purified PCR products were sequenced by Macrogen Inc., (Korea), and sequences were done in both directions.

\section{Sequence comparisons and phylogenetic analysis}

The nucleotide sequences of the resulted PCR products were initially analyzed using BLAST online database (http:www.ncbi.nlm.nih.gov) with the already submitted sequences. The sequence similarity was carried out using Muscle algorithm available in species demarcation tool (SDT) (Muhire et al., 2014) and evolutionary relationships were determined using phylogenetic analysis and the phylogenetic trees were constructed by the Neighbor-Joining method using the Kimura 2parameter (Kimura, 1980).

The analysis involved 10 nucleotide sequences. Codon positions included were 1st+2nd+3rd+Noncoding. All positions containing gaps and missing data were eliminated. There were a total of 404 positions in the final dataset. Evolutionary analyses were conducted in MEGA7 (Kumar et al., 2016).

\section{Results and Discussion}

Primer pairs used in this study produced a PCR fragments with size about 550bp (Fig. 1). Amplified fragments were sequenced in both directions and all sequences were edited using MEGA7 (Kumar et al., 2016). All obtained sequences were the same and were deposited in GenBank under the same accession number (KY404086), similar sequences were retrieved from nucleotide database on the GenBank and similarities were determined using STD. Sequences similarities of all Trichogramma cacoeciae wasps ranged from 98.3 to $99.4 \%$ while the identity between $T$. cacoeciae and $T$. californicum (AF408664) was 89.7\% (Fig. 2).
Moreover, the phylogenetic tree generated a dendogram with two sub clusters. The first one comprised all closely related wasps from Saudi Arabia, Tunisia, Iran and India while the second sub cluster contained all isolates from USA, Greece, Germany and Peru (Fig. 3).

To our knowledge this is the first report of Trichogramma cacoeciae in Alhassa, Saudi Arabia. The molecular identification using PCR of ITS-2 rDNA are the easy methods to identify the species of Trichogramma basis of their sequence differences, which were difficult to distinguish them morphologically, but this study showed that the ITS- 2 provides an excellent method for identifying Trichogramma species in Al-Hassa oasis and the results showed that the species identified is Trichogramma cacoeciae.

This method used for identification of Trichogramma species was fully supported by (Rohi and Pintureau, 2003; Nasir et al 2013) when they succeed by using ITS2 to separate closely related species of $T$. evanescens, $T$. euproctidis and T. chilotraeaewere.

In addition in many cases morphological distinguish between Trichogramma species was difficult such as distinguish between $T$. Siddiqiwas and $T$. chilonis because, since morphologically minor differences were found, but in DNA sequences there were consistent differences (Nasir et al., 2013). The identification of Trichogramma cacoeciae based on the ITS2 sequence were recorded in many different part of the world as in Peruby De Almeida and Stouthamer (2003). In many middle east countries this species was also recorded on an Apple fruit worm eggs Cydiapomonella.in Syria by Almatni, (2003), and also recorded on grape berry moth Lobesia botrana in Egypt (El-Wakeil et al., 2009), and in Iran (Lotfalizadeh et al., 2012). 
Fig.1 Results of PCR amplification products of ITS2 region of Trichogramma wasps are in lanes 1, 2, and 3. The negative control is indicated as ' $-\mathrm{Ne}$ '. The used marker was 100bp DNA Ladder obtained from Biomatik (Cat. No:M7123)

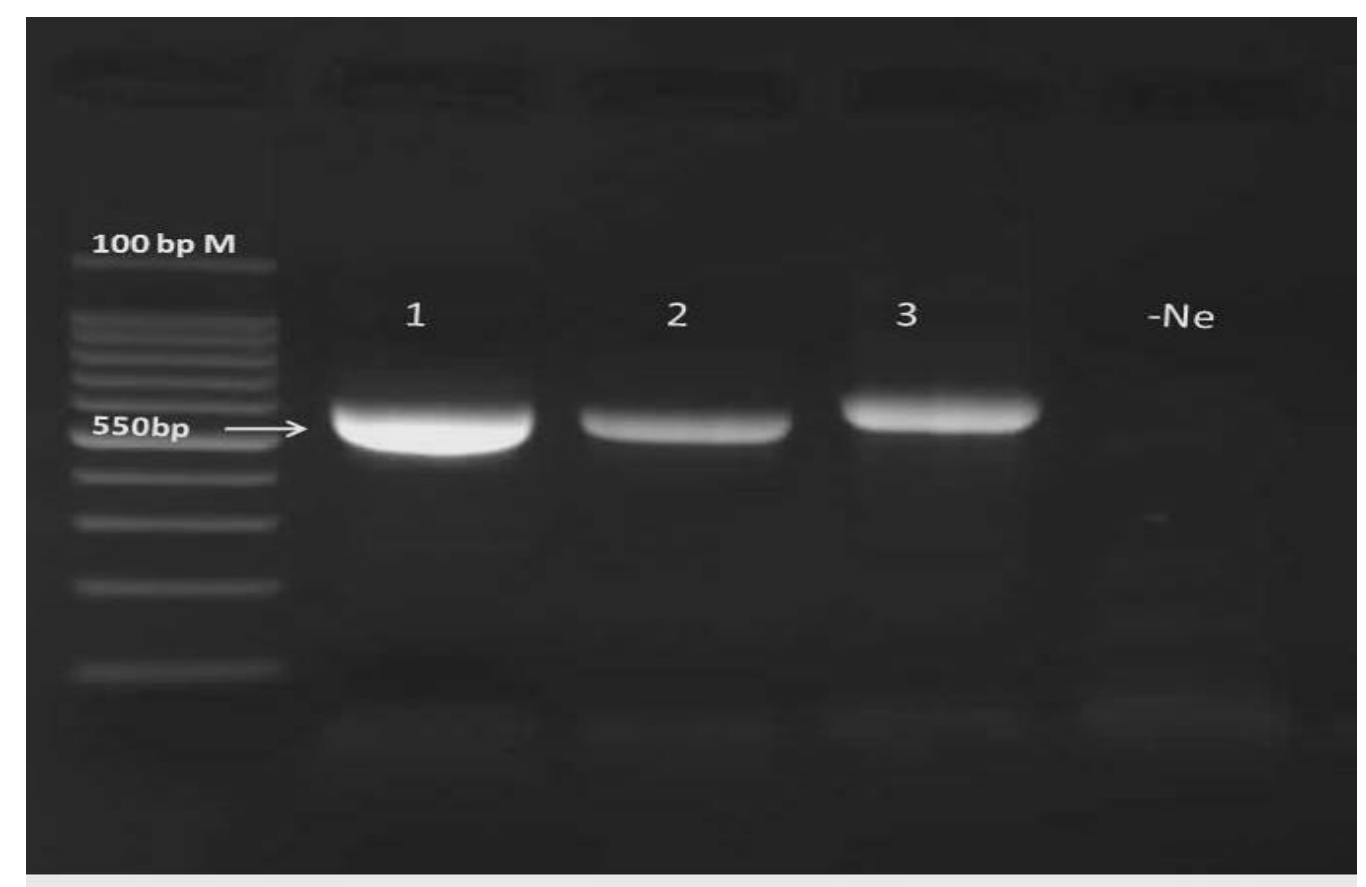

Fig.2 Pair-wise nucleotide sequence identities of the ITS region sequences of Trichogramma cacoeciae using SDT analysis. The wasp identified in this study have been highlighted with white text on a black background

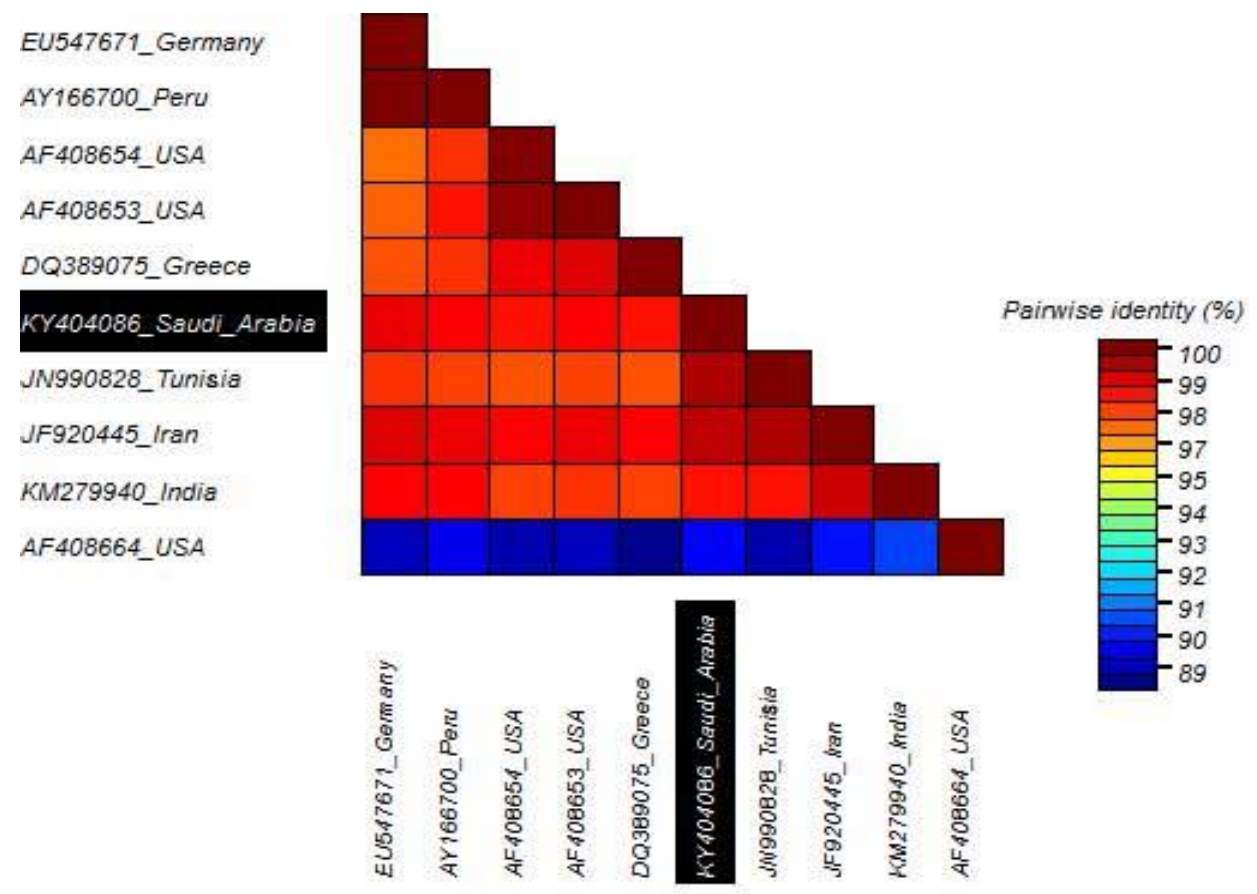


Fig.3 Phylogenetic dendograms based upon the ITS sequences to show the evolutionary relationships between wasps in this study and the previously reported wasps of Trichogramma cacoeciae. The wasp identified in this study is highlighted with white text on a black background. The tree was rooted to Trichogramma californicum (AF408664)

\begin{tabular}{|c|c|c|c|c|c|c|c|c|c|c|}
\hline & EVI577671_Germa & AY16670__Peru & AFAO8654__SA & AFA086653_USA & DQ3838075-Greece & INA444085 S & IN9908828_Tunisisi & JF920445_Iran & KM279940_India & AFAO8664_ USA \\
\hline 04986 & 98.7 & 98.5 & 98.3 & 98.5 & 98.3 & 1000.0 & 99.4 & 99.2 & 98.3 & 89.7 \\
\hline
\end{tabular}

However, T.cacoeciae is one of the 10 species molecularly identified in the Mediterranean region by using the size of the ITS2 PCR product and restriction fragment length polymorphisms of the amplicon (Sumer et al., 2009). The identification of local species of Trichogramma spp are important for mass rearing and inundated releases because they are adapted to the climate and hosts conditions and they are generally parasite the eggs of lepidopteran insects species in Alhassa field. Therefore, it is very important natural element for biological control of Lepidopteran species.

\section{References}

Almatni, W.S. (2003). Survey and study of natural enemies of Codling moth Cydia pomonella (L.) in As-Sweida and evaluation of some bio-agent measures. PhD-thesis, University of Damascus.295 pp.

Beserra,.B., parra, J.R.P. (2004). Biologia parasitismo de Trichogramma atopovirilia Oatman \& Platner Trichogramma pretiosum Riley (Hymenoptera: Trichogrammatidae) emovos de Spodopterafrugiperda (J. E. Smith) (Lepidoptera, Noctuidae). Revista Brasileira de Entomologia. 48: 119-126.

Chang, S. C., Hu, N. T., Hsin, C. Y., and Sun, C. N. (2001). Characterization of Differences between Two
Trichogramma Wasps by Molecular Markers. Biological Control, 21:75-78.

De Almeida, R. P., and Stouthame, R. (2003). Molecular Identification of Trichogramma cacoeciae Marchal (Hymenoptera: Trichogrammatidae): A New Record for Peru. Neotropical Entomology 32(2): 269-272.

El-Wakeil, N. E., Farghaly, H. T. \&Ragab, Z. A. (2009). Efficacy of Trichogramma evanescens in controlling the grape berry moth Lobesiabotrana in grape farms in Egypt. Archives of Phytopathology and Plant Protection, 42(8): 705-714.

Ercan, F. S., Oztemiz, O., Tuncbilek, A. S., and Stouthamer, R. (2011). Sequence analysis of the ribosomal DNA ITS2 Region in Two Trichogramma Species (Hymenoptera: Trichogrammatidae). Arch. Biol. Sci., Belgrade. 63 (4): 949954.

Godfray, H.C.J. (1994). Parasitoids. Behavioral and Evolutionary Ecology. Princeton University Press, Princeton, New Jersey, U.S.A.

Harris, P. (1973). The selection of effective agents for the biological control of weeds. Can. Entomol., 105: 1495- 1503.

Jiu-Sheng, Z.H.U., Mei-Li, L.I.A.N., Jing, W.A.N.G. and Shu, Q.I.N. (2010).Toxicity and safety evaluation of five insecticides on egg parasitoid, Trichogramma evanescens Westwood. Chinese Journal of Eco-Agriculture. 17: 
715-720.

Kimura, M. (1980). A simple method for estimating evolutionary rates of base substitutions through comparative studies of nucleotide sequences. Journal of molecular evolution, 16(2), 111-120.

Kumar, S., Stecher, G., and Tamura, K. (2016). MEGA7: molecular evolutionary genetics analysis version 7.0 for bigger datasets. Molecular biology and evolution, 33(7), 18701874.

Landry BS, Dextraze L, Boivin G (1993) Random amplified polymorphic DNA markers for DNA fingerprinting and genetic variability assessment of minute parasitic wasp species Hymenoptera: Mymaridae and Trichogrammatidae) used in biological control programs of phytophagous insects. Genome 36:580 587

Lotfalizadeh, H., Masnadi-Yazdinejad, A., and Saber, M. (2012) New Records of The Grape Berry Moth, Hymenopterous Parasitoids in Iran. Mun.Ent. Zool. 7(1): 284-291.

Muhire, B. M., Varsani, A., and Martin, D. P. (2014). SDT: a virus classification tool based on pairwise sequence alignment and identity calculation. PloS one, 9(9), e108277.

Nagarkatti S., Nagaraja H. (1977) Biosystematics of Trichogramma and Trichogrammatoidea species. Annu Rev Entomol 22:157-176

Nasir, M. F., Hagedorn, G., Buttner,C., Reichmuth, C., and Scholler, M. (2013). Molecular identification of Trichogramma species from Pakistan, using ITS-2 region of rDNA. BioControl, 58:483-491

ÖzderNihal and Gürkan Kara, Comparative. (2010) biology and life tables of Trichogramma cacoeciae, T. brassicae and T.evanescens (Hymenoptera: Trichogrammatidae) with Ephestia kuehniella and Cadracautella (Lepidoptera: Pyralidae) as hosts at three constant temperatures. Biocontrol Science and Technology, 20 (3): 245255

Pinto, J.D. and Stouthamer, R., (1994). Systematics of the Trichogrammatidae with emphasis on Trichogramma. In: E. WAJNBERG and S.A. HASSAN, eds. Biological control with egg parasitoids. Wallingford: CAB International, pp. 136.

Rohi L, Pintureau B (2003) Reassessment of Trichogramma euproctidis. Russ Entomol J 12:373-379

Santos, NR., Almeida, RP., Padilha, IQM., Araújo, DAM dna Creão-Duarte, AJ.(2015). Molecular identification of Trichogramma species from regions in Brazil using the sequencing of the ITS2 region of ribosomal DNA. Braz. J. Biol. 75(2): 391-395.

Silva, IMMS., Honda, J., Vankan, F., Hu, J., Neto, L ,.Pintureau, B. and Stouthamer, R., (1999). Molecular differentiation of five Trichogramma species occurring in Portugal. Biological Control, 16(2):177184.

Stimer, B. and house, G. J. (1990). Arthropods and other invertebrates in conservation tillage agriculture. Annual Review of Entomology, Stanford. 35: 299-318.

Stouthamer, R., J. Hu., F. J.P.M. Van Kan, G.R. Platner and J. D. Pinto. (1999). The utility of internally transcribed spacer 2 DNA sequences of the nuclear ribosomal gene for distinguishing sibling species of Trichogramma. BioControl 43: 421-440.

Sumer, F., Tuncbilek, A.S., Oztemiz, S., Pintureau, B., Jones, P.R, And R. Stouthamer (2009). A molecular key to the common species of Trichogramma of the Mediterranean region. BioControl. 54, 617-624. 
Thomson, L.J., Glenn, D.C. and Hoffmann, A.A. (2000). Effects of sulfur on Trichogramma egg parasitoids in vineyards: measuring toxic effects and establishing release windows. Australian Journal of Experimental Agriculture. 40, 1165-1171.

\section{How to cite this article:}

Hajjar, M.J., K.A. Alhudaib, M. Almasoud, M.I. Al-Maghaslah and El-Ganainy, S.M. 2018. Molecular Identification of Trichogramma Species Present in Alhassa Oasis. Int.J.Curr.Microbiol.App.Sci. 7(12): 2369-2376. doi: https://doi.org/10.20546/ijcmas.2018.712.268 